\title{
The problem of lending to agricultural enterprises in the context of the COVID-19 pandemic
}

\author{
Sergey Yekimovi,*, Galina Guzhina ${ }^{2}$, Pavel Lukyanov ${ }^{3}$ Olga Bespalova ${ }^{4}$, and Dmitriy \\ Kucherenko ${ }^{5}$ \\ ${ }^{1}$ Publishing House "Education and Science" s.r.o., Olstynska 607/1, Praha 8, 18100, Czech Republic \\ ${ }^{2}$ State University of Humanities and Technology, Moscow, Russia \\ ${ }^{3}$ Financial University under the Government of the Russian Federation, Moscow, Russia \\ ${ }^{4}$ Bryansk State University named after academician I.G. Petrovskiy, Bryansk, Russia \\ ${ }^{5}$ Kuban State Agrarian University, Krasnodar, Russia
}

\begin{abstract}
The main obstacle to the implementation of lending to agricultural enterprises is the high cost of credit. In our opinion, an adequate state agricultural policy should increase the interest of commercial banks in providing loans. In our opinion, it should be aimed at increasing the availability of bank loans for agricultural enterprises. For this purpose, it is advisable to partially compensate the payment of bank interest by agricultural enterprises. In the world practice in the banking sector, negative rates of return on deposits have found application. Commercial banks are able to borrow money at a discount rate. At the moment, there is a practice according to which the Central Bank has only one discount rate. In our opinion, there could be several discount rates at the same time. We hold the view that depending on the purposes to which the commercial bank directs the funds received from the Central Bank, the size of the Central Bank's discount rate may be different and even have a negative value. We believe that the negative discount rate applied by the central bank for lending to commercial banks to continue providing loans for the purchase of agricultural machinery could encourage them to issue loans to agricultural enterprises. In our opinion, the use of a negative discount rate of the Central Bank in some cases may contribute to the realization of the bank's credit potential and enhance its lending activities.
\end{abstract}

\section{Introduction}

Through credit, temporarily available funds of households, the state and enterprises are converted into loan capital, which banks transfer for temporary use for a certain fee. The movement of capital between sectors of the economy is carried out through the movement of money. Credit in a market economy ensures the migration of capital between sectors of the economy and affects the rate of return in these industries.

\footnotetext{
*Corresponding author: 3701313@mail.ru
} 
Credit is an important component of investment processes that take place in the real sector of the economy.

According to [1], the scale and level of investment activity of enterprises are the main factors that ensure the pace of economic development and the growth of its efficiency and competitiveness, as well as its development in the future.

According to [2] in the process of redistribution of funds between sectors of the economy, investment lending plays an important role.

According to [3], effective management of credit operations of a commercial bank requires a balanced credit policy that would provide for the priorities and goals of banking activities, as well as methods and means of their implementation.

According to [4], the credit policy forms the basis for the organization and functioning of bank lending on the basis of the main strategic directions of the bank's activities and is an essential condition for documenting the lending process.

According to [5], the credit policy of a commercial bank is a tactic and strategy of banking activities related to attracting depositors ' funds and lending to borrowers based on the following principles: targeted use, payment, repayment and urgency.

According to $[6,7]$, each commercial bank forms its own credit policy, taking into account possible internal and external risks.

The authors [8] identify the following main objectives of the credit policy of a commercial bank (Figure 1):

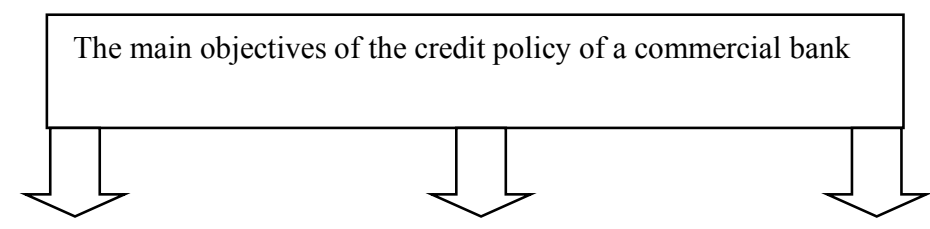

\begin{tabular}{|l|l|l|}
\hline $\begin{array}{l}\text { Implementation of loans taking } \\
\text { into account internal and external } \\
\text { risks }\end{array}$ & $\begin{array}{l}\text { Stable growth of the loan } \\
\text { portfolio }\end{array}$ & $\begin{array}{l}\text { Ensuring optimal } \\
\text { profitability of the loan } \\
\text { portfolio }\end{array}$ \\
\hline
\end{tabular}

Fig. 1. The main objectives of the credit policy of a commercial bank.

According to [9], the main principles of the formation of the credit policy of a commercial bank should contain:

1) Maintaining internal balance in certain areas of bank lending policy;

2) Ensuring the correlation of banking and credit policy;

3) Segmentation of the bank's credit policy by various types and forms of credit activity;

4) Flexible approach to the implementation of the credit policy;

5) Ensuring the formation of an effective credit potential of the bank.

According to $[10,11]$, the credit potential of a bank is the ability of a commercial bank to implement lending activities to the population and enterprises based on the financial resources available to it.

According to [12], the credit potential of a commercial bank is the maximum allowable amount of attracted and own funds that the bank can use for issuing loans.

According to [13], the credit potential is the amount of free cash available to the bank minus the liquidity in the reserve.

According to [14], the credit potential is the cash and highly liquid intangible assets at the disposal of the bank.

According to the authors [15], the credit potential is the bank's resources that it can use for lending purposes, taking into account the availability of alternative financing options. 
Based on the analysis, we have come to the conclusion that the bank's credit potential is the ability of a commercial bank to carry out lending activities to the population and enterprises based on the financial resources available to it, taking into account the implementation of necessary measures aimed at diversifying the bank's loan portfolio.

We hold the view that the bank's credit potential depends on objective and subjective factors(Figure 2):

\begin{tabular}{|l|l|}
\hline \multicolumn{3}{|c|}{ Factors affecting the size of the bank's credit potential } \\
$\begin{array}{ll}\text { 1. Professional training of banking personnel } \\
\text { 2. Skilful management of banking personnel }\end{array}$ & $\begin{array}{l}\text { Objective factors: } \\
\text { 1. Bank's equity capital } \\
\text { 2. Attracted funds of enterprises and citizens } \\
\text { 3. Financial and credit policy of the central bank } \\
\text { 4. Legislative regulation of the banking sector } \\
\text { 5. The exchange rate of the national currency } \\
\text { 6. The level of inflation }\end{array}$ \\
\hline
\end{tabular}

Fig. 2. Objective and subjective factors affecting the size of the bank's credit potential.

\section{Methods}

During the implementation of this study, the authors used an analytical method, which allowed us to study the problems considered in the work in their development and unity.

Taking into account the goals and objectives of this study, we used the structural and functional method of scientific cognition.

As a result of the study, we were able to study some of the problems of lending to agricultural enterprises in the context of the COVID-19 pandemic.

\section{Results}

In the early 2010s, some States located on the territory of the former Soviet Union made an attempt to increase agricultural production. To this end, it was decided to subsidize the purchase of agricultural machinery by agricultural enterprises. It was envisaged that part of the interest on loans for the purchase of agricultural machinery would be paid by the state. At the same time, it was required that this equipment was of domestic production. Farmers were able to purchase harvesters and tractors on credit, paying an interest rate of approximately 3-5\% per annum. All other interest was paid from the state or local budgets. As a result of these innovations, manufacturers of agricultural machinery received new orders, agricultural enterprises were able to purchase new high-performance equipment on credit on favorable terms, and food production increased, both for domestic consumption and for export sales. In the end, this led to an increase in budget revenues, a decrease in food imports and an increase in their production, and commercial banks were able to realize their credit potential.

However, in 2019, the COVID-19 pandemic began, and states were forced to reduce state support programs for lending to domestic agricultural machinery due to the need to increase health care funding. Given this, manufacturers of agricultural machinery realized that they would not be able to maintain sales of their products and were forced to reduce 
production. Commercial banks came to the conclusion that there may be problems not only with the issuance of new loans to agricultural enterprises for the purchase of new agricultural equipment, but also with payments on old loans, since they were paid from the budget, and its revenues decreased. In addition, commercial banks took into account that the production of agricultural machinery has decreased, which means that farmers will buy less domestic agricultural machinery.

Thus, the COVID-19 pandemic has led to a decrease in the credit potential of commercial banks.

The authors see the following as a way out of this situation.

In the world practice, negative rates of return on bank deposits have recently been used in banking activities.

At the same time, commercial banks can borrow money from Central banks at a discount rate. Currently, there is only one discount rate in each state. In our opinion, there could be several discount rates at the same time. We believe that depending on where the commercial bank will direct the funds received from the Central Bank, the value of the discount rate could be different and even have a negative value.

For example, a negative discount rate, in our opinion, could be applied when the funds received from the Central Bank from commercial banks would be directed to lending for the purchase of domestic agricultural machinery. In this case, it would be possible to remove the dependence of credit institutions, as well as manufacturers of agricultural machinery, on the ability of the budget to subsidize the payment of interest on agricultural machinery purchased on credit. This means that manufacturers of agricultural machinery would have an incentive to increase production volumes, and commercial banks would have an incentive to increase lending volumes. Thus, a negative discount rate of the central bank, applied in certain cases, could increase the realization of the bank's credit potential and activate its lending activities.

\section{Discussion}

Without an assessment of the real size of the credit potential and its effective use, the economic policy of the state in the agricultural sector of the economy, in our opinion, cannot be sufficiently justified. A real assessment of the size of the credit potential will reveal the full extent of the bank's financial resources, as well as possible directions for their use.

Agriculture is one of the most important branches of the Ukrainian economy. Its products not only provide food for the population, but also are raw materials for other sectors of the economy.

Currently, investors are in no hurry to invest in the agricultural sector of the economy, so loans are the most important source of financial resources for agricultural enterprises. Taking into account the specifics of agricultural production, for its successful functioning, it needs sources of fast financial resources with low interest rates and a long loan repayment period. However, commercial banks, taking into account the risks associated with the nature of agricultural production, in most cases, avoid lending to it. In our opinion, the state is required to implement a balanced agricultural policy that would promote the development of the agro-industrial complex and increase the level of competitiveness of products produced by agricultural enterprises in the foreign and domestic markets. One of the main problems faced by agricultural enterprises is the lack of working capital and the deterioration of fixed production assets.

Credit support for agricultural enterprises can assist in their effective development. In turn, the development of the economy contributes to the further evolution of the credit system. 
Thanks to loans, the development of productive forces is stimulated, as well as the concentration of capital for expanded reproduction takes place.

Through the provision of various benefits and subsidies, the state has the opportunity to focus commercial banks on the priority provision of loans to enterprises in certain sectors of the economy.

In our opinion, the main problems faced by agricultural enterprises in obtaining loans are (Figure 3):

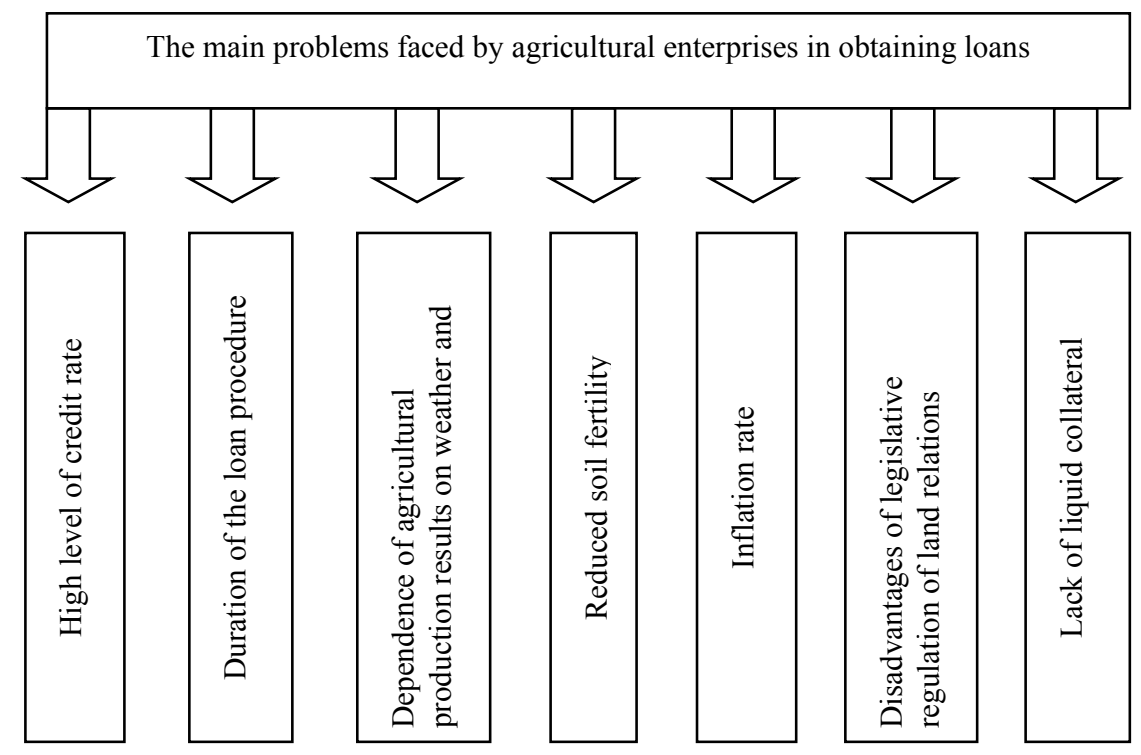

Fig. 3. The main problems faced by agricultural enterprises in obtaining loans.

Interest rates on loans for Ukrainian agricultural enterprises are quite high and are a significant financial burden for them. In the world practice, the reduction of interest rates on loans is often achieved through risk insurance. However, in Ukraine, agricultural risk insurance is currently not widely used. This is due to the high cost of such services, the complexity of concluding an insurance contract, as well as the lack of specialists in agricultural risk insurance for insurance companies.

\section{Conclusions}

Increasing the production potential of the agricultural sector of the economy, reducing its technological and economic lag, implementing technical re-equipment, moving along an innovative path of development requires attracting additional financial resources to the agricultural sector of the economy.

This leads to the need for external sources of financing. Lending to agricultural enterprises allows the use of temporarily available funds to meet the needs of agricultural producers in the need for temporary financial resources, at all stages of the production cycle.

The main obstacle to lending to agricultural enterprises is the high cost of credit. In our opinion, the agricultural policy of the state should serve to increase the interest of commercial banks in lending to agricultural enterprises. In our opinion, it should be focused on increasing the availability of bank loans for agricultural enterprises by partially compensating for the payment of bank interest and partially guaranteeing the return of loans by agricultural enterprises. 


\section{References}

1. Michael Boehlje, The Emerging Agricultural Lending System, (2019) 10.1201/9780429039744-5.

2. Nataliya Trusova, Nataliia Radchenko, Accounting and Finance, 59-67 (2020) 10.33146/2307-9878-2020-4(90)-59-67.

3. Cortney Cowley, Mapping Stress in Agricultural Lending. The Federal Reserve Bank of Kansas City Economic Review, (2018)10.18651/ER/3q18Cowley

4. Svetlana Ilyuhina, Science in figures, 23-24, (2017)10.21661/r-130110

5. D. Ghosh, Economic and Political Weekly, 40, 93-96 (2005) 10.2307/4416032.

6. Thorsten Giehler, Sources of funds for agricultural lending(2021)

7. Gary Brester, Myles Watts, Agricultural Finance Review, 79 (2018) 10.1108/AFR-042017-0025.

8. K.N. Gorpinchenko, A.M. Lyakhovetsky, O.N. Nesterenko, Scientific development trends and education, 4 (2019) 10.18411/1j-05-2019-78.

9. D.O. Zabaznova, L.A. Melikhova, Economy of agricultural and processing enterprises, 71-74 (2019) 10.31442/0235-2494-2019-0-1-71-74

10. Francisco Ascui, Theodor Cojoianu, Business Strategy and the Environment, 28, (2019) 10.1002/bse.2313.

11. Oleksii Zoria, Svitlana Zorya, Iryna Salohub, Market Infrastructure, (2020) 10.32843/infrastruct40-14.

12. Robert Braddock, \& Joseph, Agricultural lending in selected agriculturally oriented commercial banks (2021)

13. Carlos Castro, Karen Garcia, Agricultural Finance Review 74, 501-521 (2014) 10.1108/AFR-10-2013-0036

14. Meier \& Alexander, Harvey, Agricultural lending attitudes, practices and activities of Ohio commercial bankers (2021)

15. Steve Rannekleiv, Using a Subsector Development Methodology to Improve the Effectiveness of Agricultural Lending (2021) 